\title{
Dissolved organic carbon from cultured kelp Saccharina japonica: production, bioavailability, and bacterial degradation rates
}

\author{
Yaping Gao',2, Yitao Zhang ${ }^{3}$, Meirong Du ${ }^{1,2}$, Fan Lin $^{1,2}$, Weiwei Jiang ${ }^{1,2}$, \\ Wenhao Li ${ }^{4}$, Fengxue $\mathrm{Li}^{1}$, Xuning $\mathrm{Lv}^{5}$, Jinghui Fang ${ }^{1,2}$, Zengjie Jiang ${ }^{1,2, *}$ \\ ${ }^{1}$ Yellow Sea Fisheries Research Institute, Chinese Academy of Fishery Sciences, Qingdao 266071, PR China \\ ${ }^{2}$ Laboratory for Marine Fisheries Science and Food Production Processes, Pilot National Laboratory \\ for Marine Science and Technology (Qingdao), Qingdao 266237, PR China \\ ${ }^{3}$ Chudao Aquatic Products Co. Ltd., Rongcheng 264312, PR China \\ ${ }^{4}$ Shanghai Ocean University, Shanghai 201306, PR China \\ ${ }^{5}$ University of Chinese Academy of Sciences, Beijing 100049, PR China
}

\begin{abstract}
Seaweed farming is widely perceived as one of the most environmentally benign types of aquaculture activity. In the past $10 \mathrm{yr}$, global seaweed production has doubled and reached 31.8 million t. Farmed seaweed also has important functions in local ecosystems. We focus on the production, bioavailability, and bacterial degradation rates of dissolved organic carbon (DOC) from cultured kelp Saccharina japonica. Semi in situ incubations in 2 growing seasons were conducted to estimate DOC production, and laboratory incubations were used to determine bioavailability and decay rates of DOC from cultured kelp. Results showed that DOC production was $6.2-7.0 \mathrm{mg} \mathrm{C}$ (g dry wt) ${ }^{-1} \mathrm{~d}^{-1}$ in the growing seasons, and the proportion of DOC in net primary production was $23.7-39.1 \%$. The decomposition rate of DOC was $4 \pm 1 \% \mathrm{~d}^{-1}$ and $9 \pm 1 \% \mathrm{~d}^{-1}$ in January and April, respectively. About $37.8 \%$ remained as refractory DOC after $150 \mathrm{~d}$ incubation. It was calculated that the total DOC from kelp in Sanggou Bay was approximately 11.3 times of that from phytoplankton for the whole bay $\left(144 \mathrm{~km}^{2}\right)$. Our results suggest that more than half of the bioavailable DOC will be exported out of the bay to potentially support the wider food chain through bacterial uptake. Cultured kelp is therefore an important source of DOC in the embayment, contributes to the coastal DOC pool and provides a potential pathway for carbon dioxide sequestration.
\end{abstract}

KEY WORDS: Cultured kelp $\cdot$ Saccharina japonica $\cdot$ Bioavailability $\cdot$ Degradation rates $\cdot$ DOC productivity $\cdot$ Export

\section{INTRODUCTION}

Marine dissolved organic carbon (DOC) represents one of the largest and most exchangeable organic carbon pools on Earth and plays an important role in marine biogeochemical cycles. In addition to the well-recognized phytoplankton, macroalgae are also major primary producers contributing to marine

\footnotetext{
*Corresponding author: jiangzj@ysfri.ac.cn
}

newly synthesized DOC (Khailov \& Burlakova 1969, Sieburth 1969, Søndergaard 1981). The ecological role of DOC in coastal ecosystems depends on its decomposition process. Within a particular ecosystem, some of the DOC can be degraded within the system (Lønborg et al. 2009, Lønborg \& ÁlvarezSalgado 2012), rapidly utilized through biological uptake as bioavailable DOC (BDOC), remineralized 
to inorganic constituents (Ducklow et al. 1986), and reincorporated via microbial organisms (i.e. in the microbial loop, Azam et al. 1983) to higher trophic levels. On the other hand, a large proportion of the DOC will be exported out of the system to the open sea to degrade or be transformed into refractory dissolved DOC (RDOC) (Ogawa et al. 2001, del Giorgio \& Duarte 2002, Jiao et al. 2010, Lechtenfeld et al. 2015) and thus potentially contribute to global carbon sequestration (Krause-Jensen \& Duarte 2016).

Quantitative evaluation of DOC production by seaweeds depends on DOC absolute release rate and the fraction of DOC in net primary production (NPP). Laminarian brown macroalgae (kelp) release $13-62 \%$ of their photosynthetic captured carbon as DOC (Khailov \& Burlakova 1969, Abdullah \& Fredriksen 2004, Wada et al. 2007, Reed et al. 2015). The released DOC contributes to the coastal DOC pool. In some coastal environments, macroalgal DOC contribution can reach $20 \%$ of the total DOC concentrations (Wada et al. 2007, Wada \& Hama 2013). It has been shown that about $53.7 \%$ of released DOC is mineralized in $30 \mathrm{~d}$ decomposition experiments (Wada et al. 2008), and that DOC from kelp is more refractory than DOC from phytoplankton, which can be removed by bacteria in days to weeks (Kirchman et al. 1991, Chen \& Wangersky 1996, Hama et al. 2004, Davis \& Benner 2007), because bioavailability of DOC varies depending on DOC chemical composition (Benner \& Opsahl 2001, Wada et al. 2007) and production of refractory components (Cottrell \& Kirchman 2000, Lønborg et al. 2009). Data on mineralization of DOC at a longer time scale is limited. Most of the incubations lasted a few days to 2 mo (Wada et al. 2008), and the remaining refractory DOC fraction was unclear. In a particular coastal ecosystem, the DOC fate (utilization versus export) and its function in the local system will depend on the balance between the half-life of DOC and the water residence time (Lønborg \& Álvarez-Salgado 2012).

Seaweed culture is a rapidly developing industry and plays an important role in the supply of seafood and raw industrial materials. It is widely perceived as one of the most environmentally benign types of aquaculture. In 2016, global production of algae reached 31.8 million $\mathrm{t}$ (FAO 2018). In aquaculture ecosystems, the effects of macroalgae on dissolved inorganic nutrient cycles (i.e. inorganic carbon, nitrogen, phosphorus, and silicates) have received more attention (Jiang et al. 2013, Li et al. 2016, Ning et al. 2016), while DOC has not been well studied (Mahmood et al. 2017, Wang et al. 2017).

The production of macoroalgae in China accounts for $48.6 \%$ of the global supply (FAO 2018). Among the species cultured in China, the kelp Saccharina japonica is the most important. In natural kelp populations, the production of DOC shows high variability (Khailov \& Burlakova 1969, Sieburth 1969, Abdullah \& Fredriksen 2004, Reed et al. 2015). Research on DOC production in cultured kelp is limited; the bioavailability of kelp DOC remains unclear, and the function of DOC in culture systems has not been evaluated to date.

Sanggou Bay is the largest kelp culture region in north China, with a culture area of $83 \mathrm{~km}^{2}$ and production of up to $79000 \mathrm{t}$ in dry weight (Rongcheng Fisheries Technology Extension Station 2017). Kelp thallus OC is removed from the ecosystem when harvested, while DOC is released into the embayment throughout the whole period of growth. In this study, we performed (1) semi-in situ incubation to estimate DOC production by cultured S. japonica, (2) laboratory incubation to determine the bioavailability and decay rates of DOC, and (3) analysis to provide an assessment of cultured kelp as a net source of DOC that helps fuel the microbial foodweb in the nearshore water column.

\section{MATERIALS AND METHODS}

\subsection{Study site}

Sanggou Bay is a temperate semi-enclosed bay at the eastern end of the Shandong Peninsula in China $\left(122^{\circ} 24^{\prime}-122^{\circ} 35^{\prime} \mathrm{E}, 37^{\circ} 01^{\prime}-37^{\circ} 09^{\prime} \mathrm{N}\right)$. The north, west, and south sides of the bay are surrounded by land, and the mouth opens into the Yellow Sea (Fig. 1). The bay is approximately $11.5 \mathrm{~km}$ in length and $7.5 \mathrm{~km}$ in width from east to west, with an area of $144 \mathrm{~km}^{2}$. The average water depth is $7.5 \mathrm{~m}$ and the maximum offshore water depth reaches $33 \mathrm{~m}$. The seasonal variation in water temperature in the bay is 1.8-26. $2^{\circ} \mathrm{C}$, and salinity is $29.1-31.8 \mathrm{psu}$ (Zhu et al. 2017). Kelp is the most important aquaculture species in the bay and typically cultivated from November to the following May to July using the suspended longline method.

\subsection{Incubation and sampling method}

We performed incubations in Sanggou Bay in late January and late April, representing the winter and spring farming seasons, respectively. An outdoor semi-in situ culture system was established in the dock and used for the incubations (Fig. 2). In this 


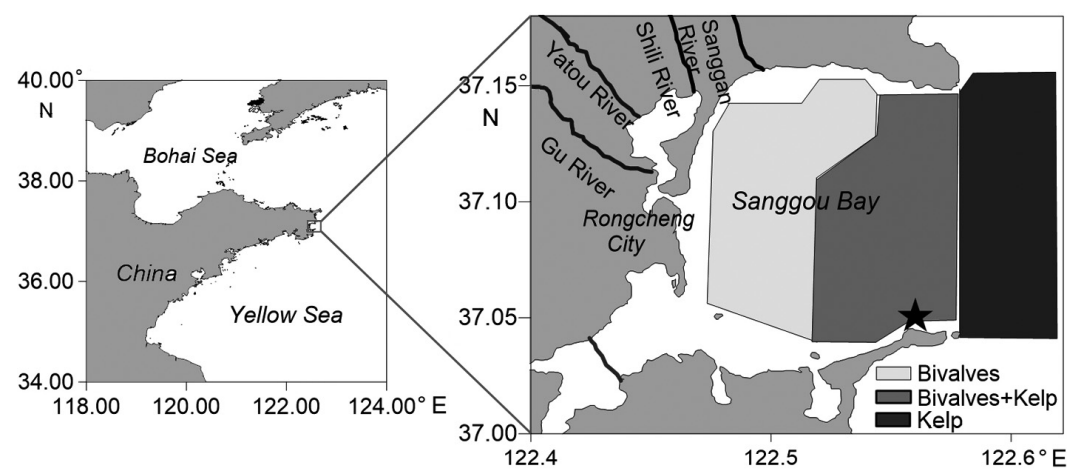

Fig. 1. Sanggou Bay, China, showing the culture areas and the incubation experiment site $(\star)$

system, $125 \mathrm{l}$ cylindrical acrylic containers $(40 \mathrm{~cm}$ in diameter and $100 \mathrm{~cm}$ in height) were placed in a large storage tank $(4 \mathrm{~m} \times 3 \mathrm{~m} \times 0.9 \mathrm{~m})$ into which seawater was continually pumped $\left(40 \mathrm{~m}^{3} \mathrm{~h}^{-1}\right)$ to maintain a water temperature similar to that of the kelp's natural environment. Kelps were collected from longline culture ropes in Sanggou Bay and transported to the storage tank in water within 15 min.

A single plant was introduced into each of the 6 cylinder containers $(\mathrm{n}=6)$, while 3 containers without kelp served as controls $(n=3)$. Submersible pumps were placed on the side wall of each container to simulate the hydrodynamic conditions in a natural culture environment (with velocities of approximately $0.06 \mathrm{~m} \mathrm{~s}^{-1}$, measured by JFE Advantech Model AEM - USB current meters hung in the container). Kelps were hung in the tops of the containers in the same manner as in the longline culture (Fig. 2). Due to the short time out of water during collection, kelps were acclimated for 1 day in the containers in flowing water. Then seawater was changed and incubation experiments began. Silicon rubbers were used to plug the openings in the cylinder container. The incubation lasted for $25 \mathrm{~h}$, to cover the whole tidal cycle.

During the incubation, oxygen and temperature in each container were measured using a dissolved oxygen portable meter (Orion3-star, Thermo Electron) every $2 \mathrm{~h}$ during the day and $6 \mathrm{~h}$ during the night (smaller change during the night than the day) to evaluate NPP and respiration $(R)$. All of the 6 replicate containers were used to calculate the NPP and $R$. Light intensity of the surface water (at a depth about $0.5-1 \mathrm{~cm}$ ) in a randomly selected control container was recorded continuously by a PAR logger (DEFI2$\mathrm{L}$, JFE Advantec). The light vertical attenuation coefficient $(K)$ in control containers $(\mathrm{n}=3)$ was calculated from the slope of the linear regression of the natural logarithm of PAR. versus depth.

Three replicate $30 \mathrm{ml}$ samples were extracted by glass pipette from each container at the beginning and end of the incubation for evaluation of DOC concentration. After filtering through $0.7 \mu \mathrm{m}$ Whatman GF/F glass fibre filters, the water was stored in glass bottles and sealed in bubble-free states. Then the water samples were placed on ice and transported to the laboratory. The pipettes, glass bottles and GF/F filters that had been previously used were all pre-combusted $\left(450^{\circ} \mathrm{C}, 5 \mathrm{~h}\right)$.

The water volume of each container and the mass (wet weight and dry weight) and length of each kelp was determined at the end of the incubation and used to determine the primary production and DOC production for each kelp plant. Triplicate water samples in each container were filtered through a $0.45 \mu \mathrm{m}$ Millipore cellulose membrane filter and transported to the laboratory for inorganic nutrient analyses. Nitrate $\left(\mathrm{NO}_{3}{ }^{-}\right)$and ammonium $\left(\mathrm{NH}_{4}{ }^{+}\right)$were analyzed using the standard pink azo-dye and phenol hypochlorite-indophenol blue method methods, respectively. Phosphate $\left(\mathrm{PO}_{4}^{-}\right)$was determined using the molybdenum-blue method. All of the above dissolved inorganic nutrient analyses followed the methods of Parsons et al. (1984).



Fig. 2. Schematic diagram of the incubation experiment system. The cylinder containers (40 cm in diameter and $100 \mathrm{~cm}$ in height) were placed in a large storage tank into which seawater was continually pumped to maintain a water temperature similar to that of natural seawater. Submersible pumps were placed on the side wall of cylinder to simulate the hydrodynamic conditions in the field 
Three replicates of 21 water were also sampled for each cylinder container for the biodegradation experiment. In the laboratory, 1.51 water samples were filtered through $0.7 \mu \mathrm{m} \mathrm{GF/F}$ filters and transferred to 21 amber glass bottles. Then, $75 \mathrm{ml}$ water samples were filtered through $1.2 \mu \mathrm{m}$ GF/C filters and added as inoculum to the 1.51 water to establish amicrobial culture (Lønborg et al. 2009). The use of GF/C filters allowed for the passage of both autotrophic and heterotrophic microorganisms that were $<1.2 \mu \mathrm{m}$, while autotrophic growth was prevented during the incubation in the dark. The experiments were conducted in the dark over a period of $150 \mathrm{~d}$ at $4^{\circ} \mathrm{C}$ and $14^{\circ} \mathrm{C}$ for the January and April samples, respectively. This time scale allows the decay of both the labile and semi-labile parts of the DOC pool. Samples of $30 \mathrm{ml}$ of water were taken at Days $0,5,15$, 30, 60, 90, and 150 and analyzed immediately after sampling.

\subsection{Analytical methods, calculations and statistical analyses}

NPP and $R$ in the 6 containers were estimated using changes in dissolved oxygen concentration in each container, based on the difference in $\mathrm{O}_{2}$ concentration during the time samples spent in illumination and the dark, respectively. Gross primary production (GPP) was calculated as the sum of NPP and $R$. Oxygen evolution rates were converted to carbon using a photosynthetic quotient of 1 (Rosenberg et al. 1995). Primary production and respiration for each plant were normalized by their dry weight.

The difference in DOC between the beginning and end of the incubation period (water was not changed during the incubation) in each control container was considered as the DOC production by phytoplankton or consumption by planktonic microbes The DOC value in the controls was subtracted from the value in kelp containers to yield the DOC production of kelp. DOC concentration in the filtered water samples was measured using the high-temperature catalytic oxidation (HTCO) technique using a $\mathrm{CN}$ analyzer (TOC-VCPH, Shimadzu) (water samples were fed directly and analyzed).

The kinetics of DOC degradation were described by a first-order exponential decay model with the refractory pool taken into account:

$$
\mathrm{DOC}(t)=\mathrm{BDOC} \cdot \exp \left(-k_{\mathrm{DOC}} \cdot t\right)+\mathrm{DOC}(150)
$$

where $\mathrm{DOC}(t)$ is the amount of DOC remaining at time $t$ for the control and kelp treatments. The control measures are subtracted from the kelp measures at each time $t$ to prevent microorganism sources of DOC from being considered as kelp sources. BDOC (in $\mathrm{mg} \mathrm{l}^{-1}$ ) is the degraded DOC during the $150 \mathrm{~d}$ period, $k_{\mathrm{DOC}}$ the degradation rate constant, calculated by the fitting the decay model (in $\mathrm{d}^{-1}$ ), $t$ is time (d), and DOC(150) (in $\mathrm{mg} \mathrm{l}^{-1}$ ) is the remaining RDOC pool after $150 \mathrm{~d}$ of incubation.

A $t$-test was used to detect if NPP, GPP, $R$ and DOC production rate were different between the 2 months using SPSS 17.0. The significance level was set at 0.05 for all tests.

\section{RESULTS}

Temperature ranged from -1.3 to $1.7^{\circ} \mathrm{C}$ during the January incubation and 14.7 to $17.8^{\circ} \mathrm{C}$ in April (Table 1). Surface PAR for the January incubations was 0-1482 $\mu \mathrm{mol} \mathrm{m} \mathrm{m}^{-2} \mathrm{~s}^{-1}$ with the PAR diffuse attenuation coefficient $(K)=2.18$. In April the surface light were $0-1928 \mu \mathrm{mol} \mathrm{m} \mathrm{m}^{-2} \mathrm{~s}^{-1}$ and $K$ was 1.47 . During $24 \mathrm{~h}$ incubations, 19.2, 30.0, and $13.9 \%$ of $\mathrm{NO}_{3}{ }^{-}, \mathrm{NH}_{4}{ }^{+}$ and $\mathrm{PO}_{4}^{-}$, respectively, were absorbed in January and 54.1, 69.5, and $27.3 \%$ in April.

Table 1. Kelp and water parameters in the incubation containers. Data are mean \pm SE (where applicable)

\begin{tabular}{|lcc|}
\hline & January & April \\
\hline Kelp dry weight (end of incubation, $g)$ & $7.23 \pm 2.15$ & $39.3 \pm 9.15$ \\
Kelp wet weight $(\mathrm{g})$ & $103.1 \pm 24.2$ & $316.5 \pm 53.3$ \\
Kelp length $(\mathrm{cm})$ & $73.6 \pm 6.6$ & $129.6 \pm 20.4$ \\
Temperature $\left({ }^{\circ} \mathrm{C}\right)$ & -1.3 to 1.7 & 14.7 to 17.8 \\
Surface irradiance $\left(\mu \mathrm{mol} \mathrm{m}{ }^{-2} \mathrm{~s}^{-1}\right)$ & 0 to 1482 & 0 to 1928 \\
$\mathrm{PAR}$ attenuation coefficient $K$ & $2.18 \pm 0.17$ & $1.47 \pm 0.37$ \\
$\mathrm{NO}_{3}^{-}\left(\right.$average initial to end, $\left.\mu \mathrm{mol} \mathrm{l}{ }^{-1}\right)$ & $8.4 \pm 0.3$ to $6.8 \pm 1.2$ & $7.4 \pm 0.6$ to $3.4 \pm 0.9$ \\
$\mathrm{NH}_{4}{ }^{+}\left(\mu \mathrm{mol} \mathrm{l}^{-1}\right)$ & $2.4 \pm 0.04$ to $1.69 \pm 0.69$ & $2.6 \pm 0.1$ to $0.8 \pm 0.4$ \\
$\mathrm{PO}_{4}^{-}\left(\mu \mathrm{mol} \mathrm{l}^{-1}\right)$ & $0.36 \pm 0.02$ to $0.31 \pm 0.04$ & $0.33 \pm 0.01$ to $0.24 \pm 0.05$ \\
$\mathrm{DOC}\left(\mathrm{mg} \mathrm{l}^{-1}\right)$ & $3.5 \pm 0.05$ to $3.92 \pm 0.97$ & $3.9 \pm 0.11$ to $5.7 \pm 1.6$ \\
\hline
\end{tabular}


The NPP of kelp in January was $29.7 \mathrm{mg} \mathrm{C}$ (g dry wt) $)^{-1} \mathrm{~d}^{-1}$ (Fig. 3), which was significantly higher than the $15.9 \mathrm{mg} \mathrm{C}$ (g dry wt) $)^{-1} \mathrm{~d}^{-1}$ in April $(\mathrm{p}<0.05) . R$ was $4.3 \mathrm{mg} \mathrm{C}$ (g dry wt) $)^{-1}$ $\mathrm{d}^{-1}$ in January, while in April the respiration reached $10.7 \mathrm{mg} \mathrm{C}(\mathrm{g} \text { dry wt) })^{-1}$ $\mathrm{d}^{-1}$. GPP was 34.0 and $26.7 \mathrm{mg} \mathrm{C}(\mathrm{g}$ dry wt $)^{-1} d^{-1}$ in January and April, respectively (Fig. 3).

The DOC production rate was $7.0 \mathrm{mg}$ C (g dry wt) ${ }^{-1} \mathrm{~d}^{-1}$ in January and $6.24 \mathrm{mg} \mathrm{C}(\mathrm{g} \text { dry } w t)^{-1} \mathrm{~d}^{-1}$ in April (Fig. 4). The proportion of DOC to NPP was 23.7 and $39.1 \%$ in January and April, respectively, with a mean value of $31.4 \%$. No significant difference was found between the 2 incubations for both the DOC production rate and DOC to NPP ( $p>0.05)$.

The incubation for the degradation of kelp DOC showed that BDOC production was $4.23 \mathrm{mg} \mathrm{C}$ (g dry wt) ${ }^{-1} \mathrm{~d}^{-1}$ in January and $3.83 \mathrm{mg} \mathrm{C}$ (g dry wt) ${ }^{-1} \mathrm{~d}^{-1}$ in April (Fig. 5). After the $150 \mathrm{~d}$ decay, 37.3 and $38.2 \%$ were left as RDOC for the January and April incubation, respectively. No significant difference was detected for the DOC release rate and bioavailability and refractory DOC production rate $(\mathrm{p}>0.05)$. The decomposition rate from the first-order exponential decay model showed that DOC was degraded at a rate of $4 \pm 1 \% \mathrm{~d}^{-1}$ and $9 \pm 1 \% \mathrm{~d}^{-1}$ in the January and April incubation, respectively (Fig. 6), and the corresponding half-life times of BDOC $\left(\ln 2 / k_{\mathrm{DOC}}\right)$ were $15.8 \mathrm{~d}$ and $5.3 \mathrm{~d}$, respectively.

The water residence time in Sanggou Bay is about $16.6 \mathrm{~d}$ in the middle part, $2.1-8.3 \mathrm{~d}$ in the outer kelp culture area, and $<2.1 \mathrm{~d}$ in the outer area of the bay

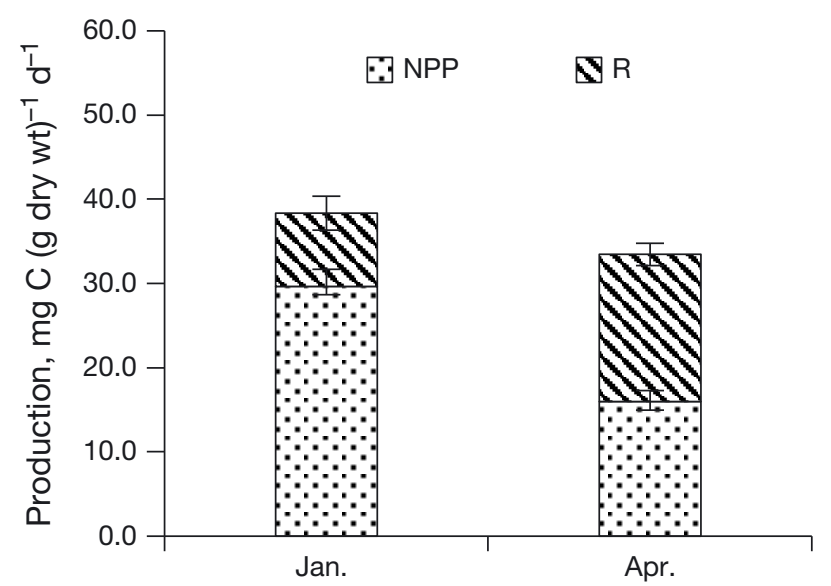

Fig. 3. Primary production of kelp in the January and April incubations. Data are mean $\pm \mathrm{SD}, \mathrm{n}=6$
(Shi \& Wei 2009). Kelp culture is mainly in the outer area of the bay (Fig. 1). Therefore, calculated using the range of values of 2.1 to $8.3 \mathrm{~d}, 8.8-30.6 \%$ and $23.9-66.0 \%$ of BDOC will be mineralized in the system in January and April, respectively, while



Fig. 5. Total DOC, bioavailable dissolved organic carbon (BDOC), and refractory dissolved organic carbon (RDOC) in the January and April incubations. Data are mean $\pm S D, n=6$



Fig. 6. Decay of bioavailable dissolved organic carbon (BDOC) from sample water collected during the January and April incubations. The solid line represents the predictions of the exponential decay model, values are mean $\pm \mathrm{SD}$,

$$
\mathrm{n}=6
$$


69.4-91.2\% and 34.0-76.1\% will be exported out of the bay, respectively, entering the Yellow Sea, where no kelp is cultured and phytoplankton is the main primary producer.

\section{DISCUSSION}

Both the absolute release rate of DOC and the proportion of DOC in NPP are important in evaluating the function of macroalgae in biological cycling of carbon (Krause-Jensen \& Duarte 2016). The development of methods such as in situ experiments allows for better quantification of the function of kelp (Wada et al. 2007, Reed et al. 2015). In the present research, we conducted the study in a semi-in situ system using entire kelp individuals and extended the study time through day and night to accurately quantify NPP and DOC production. In the 2 incubations, though the temperature in January was near freezing point, the cultured cold-water kelp species Saccharina japonica maintained strong photosynthesis and growth (Zhang et al. 2012) and showed a higher NPP than in April (Fig. 3), when the temperature (Table 1) far exceeded the optimum temperature range of $5-10^{\circ} \mathrm{C}$ for kelp growth (Zhang 1992). DOC production was 6.2$7.0 \mathrm{mg} \mathrm{C}$ (g dry wt) ${ }^{-1} \mathrm{~d}^{-1}$ (Fig. 4) and was comparable with the release rates of DOC by the uncultured kelp Macrocystis pyrifera (about 1.2-4.8 mg C [g dry wt $]^{-1}$ $\mathrm{d}^{-1}$ ) in Santa Barbara, California, USA in in situ incubations (Reed et al. 2015) and with the uncultured Ecklonia cava Kjellman, by in situ field bag experiments in Oura Bay, Japan (range: 0.12 and $5.8 \mathrm{mg} \mathrm{C}$ [g dry wt] $d^{-1}$ ) (Wada et al. 2007). NPP values in the present study were higher than those of kelp Laminaria hyperborea along the west coast of Norway (Abdullah \& Fredriksen 2004), while the fraction of DOC to NPP was comparable $(26 \%$ along west coast of Norway and $31.4 \%$ in the present study). DOC to NPP in our present study also fell within the range of the previous studies for E. cava (18-62\%, Wada et al. 2007 ) and $23-62 \%$ of the NPP for various macroalgae such as brown, red, and green algae (Khailov \& Burlakova 1969, Sieburth 1969, Wyatt et al. 2014). The above compatibility suggests that the release rate of DOC depends on, to some extent, NPP.

There are few studies on the effect of temperature on the release and decay of DOC from macroalgae (Reed et al. 2015, Iñiguez et al. 2016). Existing studies on the phytoplankton DOC response to temperature can provide some comparison. For example, Watanabe (1980) found that DOC to NPP increased when the temperature was too high or too low.
Although phytoplankton populations exhibit different temperature response characteristics in different environments or among different phytoplankton species (Watanabe 1980, Verity 1981, Zlotnik \& Dubinsky 1989), a common finding of these studies is that DOC to NPP increases only when extreme temperatures inhibit photosynthesis. High temperatures can increase the mobility of cell membrane molecules, which directly leads to an increase in the rate of transmembrane transport of substances (Myklestad \& Swift 1998). In our data, DOC to NPP in April was higher than that in January with the insignificant difference due to the variability. A valid explanation would be that the water temperature ranged from $14.7-17.8^{\circ} \mathrm{C}$ in April far exceeded the optimum temperature range of $5-10^{\circ} \mathrm{C}$ for kelp growth and photosynthesis (Zhang 1992). The high temperature likely caused the electrolyte permeability of the cytoplasmic membrane to increase and the stability of the membrane to deteriorate ${ }_{i}$, thus more organic matter synthesized by photosynthesis was released in the form of DOC. Studies also have shown that temperature affects the decomposition rate of BDOC (Middelboe \& Lundsgaard 2003, Kirchman et al. 2005, 2009, Lønborg et al. 2009). The lower BDOC decomposition rate in January than in April was due to the lower incubation temperature at which the biological reaction rates were low.

In addition to temperature, light availability (Mague et al. 1980, Verity 1981, Zlotnik \& Dubinsky 1989, Mueller et al. 2014) and nutrients (Haas et al. 2010, Barrón et al. 2012) are among the factors that are proposed to alter DOC release rates by primary producers. A similar phenomenon, frequently observed in different studies, is that the absolute amount of DOC increases with increasing light intensity (Zlotnik \& Dubinsky 1989). However, when algae deplete the limiting nutrient, cell growth and photosynthetic rates are significantly reduced (Mague et al. 1980, Børsheim et al. 2005), the absolute amount of DOC release decreases, while the DOC to NPP percent increases (Myklestad et al. 1989, Granum et al. 2002). In the April incubation, the higher DOC to NPP may also be related to nutrient depletion (Table 1), where the rate of carbon sequestration exceeds the rate of cellular component synthesis and the excess photosynthetic products actively released as DOC in an overflow mechanism (Konopka \& Schnur, 1981, Wood \& Van Valen 1990).

Bioavailability is an important factor controlling the dynamics of marine DOC. Previous studies on DOC bioavailability were mostly carried out in relatively short-term cultivation experiments (5-30 d, De 
from ocean margins to the open ocean interior could be more than an order of magnitude greater than inputs of recently produced organic carbon derived from the surface ocean (Bauer \& Druffel 1998).

Kelp farming is rapidly developing in China (China Fishery Statistical Yearbook 2019). Although, in our study, the majority of new DOC from kelp was BDOC and mineralized within months the remaining RDOC amounted to $37.8 \%$, which may be further transformed by microbes to degraded DOC that is highly resistant to microbial decomposition (Jiao et al. 2010, Lechtenfeld et al. 2015), as was the case of DOC from photosynthetic plankton consumed by heterotrophs and transformed to resistant carbon (del Giorgio \& Duarte 2002). Thus DOC from farmed kelp can eventually contribute to carbon sequestration through the microbial carbon pump (MCP) (Jiao et al. 2018), and kelp aquaculture offers a pathway of carbon sequestration and provides a potential method to help fulfill China's mission to reduce greenhouse gas emissions.

Acknowledgements. This study was funded by the Key Programme for International Cooperation on Scientific and Technological Innovation, Ministry of Science and Technology (2017YFE0118300); the Director Project by Pilot National Laboratory for Marine Science and Technology (Qingdao) (grant no. QNLM201707), the National Natural Science Foundation of China (41676147), the Youth Talent Program Supported by Laboratory for Marine Fisheries Science and Food Production Processes (2018-MFS-T13), and The Young Taishan Scholars Program of Shandong Province (tsqn201909166). We are grateful to the esteemed anonymous reviewers for their generous time and expertise in improving our manuscript.

\section{LITERATURE CITED}

Abdullah MI, Fredriksen S (2004) Production, respiration and exudation of dissolved organic matter by the kelp Laminaria hyperborea along the west coast of Norway. J Mar Biol Assoc UK 84:887-894

Amon RMW, Benner R (1994) Rapid cycling of high-molecular-weight dissolved organic matter in the ocean. Nature 369:549-552

Arnosti C, Durkin S, Jeffrey WH (2005) Patterns of extracellular enzyme activities among pelagic marine microbial communities: implications for cycling of dissolved organic carbon. Aquat Microb Ecol 38:135-145

Azam F, Fenchel T, Field JG, Gray JS, Meyer-Reil LA, Thingstad F (1983) The ecological role of water-column microbes in the sea. Mar Ecol Prog Ser 10:257-263

Barrón C, Apostolaki ET, Duarte CM (2012) Dissolved organic carbon release by marine macrophytes. Biogeosciences Discuss 9:1529-1555

Bauer JE, Druffel ER (1998) Ocean margins as a significant source of organic matter to the deep open ocean. Nature 392:482-485

Benner R, Opsahl S (2001) Molecular indicators of the sources and transformations of dissolved organic matter in the Mississippi river plume. Org Geochem 32:597-611

*Børsheim KY, Vadstein O, Myklestad SM, Reinertsen H, Kirkvold S, Olsen Y (2005) Photosynthetic algal production, accumulation and release of phytoplankton storage carbohydrates and bacterial production in a gradient in daily nutrient supply. J Plankton Res 27:743-755

* Charpy L, Roubaud-Charpy CJ (1990) A model of the relationship between light and primary production in an atoll lagoon. J Mar Biol Assoc UK 70:357-369

Chen W, Wangersky PJ (1996) Rates of microbial degradation of dissolved organic carbon from phytoplankton cultures. J Plankton Res 18:1521-1533

China Fishery Statistical Yearbook 2019. Chinese Agric Press, Beijing (in Chinese)

Cottrell MT, Kirchman DL (2000) Natural assemblages of marine proteobacteria and members of the CytophagaFlavobacter cluster consuming low-and high-molecularweight dissolved organic matter. Appl Environ Microbiol 66:1692-1697

Davis J, Benner R (2007) Quantitative estimates of labile and semi-labile dissolved organic carbon in the western Arctic Ocean: A molecular approach. Limnol Oceanogr 52: 2434-2444

De Vittor C, Larato C, Umani SF (2009) The application of a plug-flow reactor to measure the biodegradable dissolved organic carbon (BDOC) in seawater. Bioresour Technol 100:5721-5728

del Giorgio PA, Duarte CM (2002) Respiration in the open ocean. Nature 420:379

Nucklow HW, Purdie DA, Williams PJL, Davies JM (1986) Bacterioplankton: a sink for carbon in a coastal marine plankton community. Science 232:865-867

Fang J, Jiang Z, Lin F, Gao Y and others (2020) Analysis on the advantages of standard kelp long line culture in Sanggou Bay. Prog Fish Sci 41:134-140 (in Chinese with English abstract)

FAO (2018) The state of world fisheries and aquaculture 2018: meeting the sustainable development goals. FAO, Rome

*Granum E, Kirkvold S, Myklestad SM (2002) Cellular and extracellular production of carbohydrates and amino acids by the marine diatom Skeletonema costatum: diel variations and effects of $\mathrm{N}$ depletion. Mar Ecol Prog Ser 242:83-94

*Haas AF, Naumann MS, Struck U, Mayr C, el-Zidah M, Wild C (2010) Organic matter release by coral reef associated benthic algae in the Northern Red Sea. J Exp Mar Biol Ecol 389:53-60

*Hama T, Yanagi K, Hama J (2004) Decrease in molecular weight of photosynthetic products of marine phytoplankton during early diagenesis. Limnol Oceanogr 49: 471-481

Iñiguez C, Carmona R, Lorenzo MR, Niell FX, Wiencke C, Gordillo FJ (2016) Increased temperature, rather than elevated $\mathrm{CO} 2$, modulates the carbon assimilation of the Arctic kelps Saccharina latissima and Laminaria solidungula. Mar Biol 163:248

Jiang Z, Fang J, Mao Y, Han T, Wang G (2013) Influence of seaweed aquaculture on marine inorganic carbon dynamics and sea-air $\mathrm{CO}_{2}$ flux. J World Aquacult Soc 44: 133-140

Jiang Z, Du M, Fang J, Yaping G, Jiaqi L, Li Z, Jianguang F (2017) Size fraction of phytoplankton and the contribution of natural plankton to the carbon source of Zhikong 
scallop Chlamys farreri in mariculture ecosystem of the Sanggou Bay. Acta Oceanol Sin 36:97-105

Jiao N, Herndl GJ, Hansell DA, Benner R and others (2010) Microbial production of recalcitrant dissolved organic matter: long-term carbon storage in the global ocean. Nat Rev Microbiol 8:593-599

Jiao N, Wang H, Xu G, Aricò S (2018) Blue carbon on the rise: challenges and opportunities. Natl Sci Rev 5: 464-468

Khailov KM, Burlakova ZP (1969) Release of dissolved organic matter by marine seaweeds and distribution of their total organic production to inshore communities. Limnol Oceanogr 14:521-527

Kirchman DL, Suzuki Y, Garside C, Ducklow HW (1991) High turnover rates of dissolved organic carbon during a spring phytoplankton bloom. Nature 352:612-614

K Kirchman DL, Malmstrom RR, Cottrell MT (2005) Control of bacterial growth by temperature and organic matter in the Western Arctic. Deep Sea Res II 52:3386-3395

Kirchman DL, Morán XAG, Ducklow H (2009) Microbial growth in the polar oceans-role of temperature and potential impact of climate change. Nat Rev Microbiol 7: 451-459

Konopka A, Schnur M (1981) Biochemicl composition and photosynthetic carbon metabolism of nutrient limited cultures of Merimopedia tenuissima (Cyanophyceae). J Phycol 17:118-122

Kragh T, Søndergaard M (2009) Production and decomposition of new DOC by marine plankton communities: carbohydrates, refractory components and nutrient limitation. Biogeochemistry 96:177-187

Krause-Jensen D, Duarte CM (2016) Substantial role of macroalgae in marine carbon sequestration. Nat Geosci 9:737-742

* Lechtenfeld OJ, Hertkorn N, Shen Y, Witt M, Benner R (2015) Marine sequestration of carbon in bacterial metabolites. Nat Commun 6:6711

Li R, Liu S, Zhang J, Jiang Z, Fang J (2016) Sources and export of nutrients associated with integrated multitrophic aquaculture in Sanggou Bay, China. Aquacult Environ Interact 8:285-309

* Lindell MJ, Granéli W, Tranvik LJ (1995) Enhanced bacterial growth in response to photochemical transformation of dissolved organic matter. Limnol Oceanogr 40:195-199

Liu CG (2012) Study on photosynthetically produced dissolved organic carbon released of marine phytoplankton in China coastal seas. PhD dissertation, Ocean University of China, Qingdao

Lønborg C, Álvarez-Salgado XA (2012) Recycling versus export of bioavailable dissolved organic matter in the coastal ocean and efficiency of the continental shelf pump. Global Biogeochem Cycles 26:GB3018

* Lønborg C, Álvarez-Salgado XA, Davidson K, Miller AE (2009) Production of bioavailable and refractory dissolved organic matter by coastal heterotrophic microbial populations. Estuar Coast Shelf Sci 82:682-688

Mague TH, Friberg E, Hughes DJ, Morris I (1980) Extracellular release of carbon by marine phytoplankton; a physiological approach 1. Limnol Oceanogr 25:262-279

* Mahmood T, Fang J, Jiang Z, Ying W, Zhang J (2017) Seasonal distribution, sources and sink of dissolved organic carbon in integrated aquaculture system in coastal waters. Aquacult Int 25:71-85

Martinez J, Smith DC, Steward GF, Azam F (1996) Variability in ectohydrolytic enzyme activities of pelagic marine bacteria and its significance for substrate processing in the sea. Aquat Microb Ecol 10:223-230

Middelboe M, Lundsgaard C (2003) Microbial activity in the Greenland Sea: role of DOC lability, mineral nutrients and temperature. Aquat Microb Ecol 32:151-163

Moran MA, Zepp RG (1997) Role of photoreactions in the formation of biologically labile compounds from dissolved organic matter. Limnol Oceanogr 42:1307-1316

Mueller B, Van Der Zande RM, Van Leent PJM, Meesters EH, Vermeij MJ, Van Duyl FC (2014) Effect of light availability on dissolved organic carbon release by Caribbean reef algae and corals. Bull Mar Sci 90:875-893

Myklestad SM, Swift E (1998) A new method for measuring soluble cellular organic content and a membrane property, Tm, of planktonic algae. Eur J Phycol 33:333-336

*Myklestad S, Holm-Hansen O, Vårum KM, Volcani BE (1989) Rate of release of extracellular amino acids and carbohydrates from the marine diatom Chaetoceros affinis. J Plankton Res 11:763-773

Newell RC, Lucas MI, Linley EAS (1981) Rate of degradation and efficiency of conversion of phytoplankton debris by marine microorganisms. Mar Ecol Prog Ser 6:123-136

Ning Z, Liu S, Zhang G, Ning X and others (2016) Impacts of an integrated multi-trophic aquaculture system on benthic nutrient fluxes: a case study in Sanggou Bay, China. Aquacult Environ Interact 8:221-232

* Ogawa H, Amagai Y, Koike I, Kaiser K, Benner R (2001) Production of refractory dissolved organic matter by bacteria. Science 292:917-920

Parsons TR, Takahashi M, Hargrave B (1977) Biological oceanographical processes. 2nd edn. Pergamon Press, New York, NY

Parsons T, Maita Y, Lalli C (1984) A manual of chemical and biological methods for seawater analysis. Pergamon Press, Oxford

Keed DC, Carlson CA, Halewood ER, Nelson JC, Harrer SL, Rassweiler A, Miller RJ (2015) Patterns and controls of reef-scale production of dissolved organic carbon by giant kelp Macrocystis pyrifera. Limnol Oceanogr 60: 1996-2008

* Rivkin RB, Anderson MR (1997) Inorganic nutrient limitation of oceanic bacterioplankton. Limnol Oceanogr 42: 730-740

Rongcheng Fisheries Technology Extension Station (2017) Marine fishery statistics data. Fishery Technology Station of Rongcheng City, Rongcheng (in Chinese)

* Rosenberg G, Littler DS, Littler MM, Oliveira EC (1995) Primary production and photosynthetic quotients of seaweeds from Sao Paulo State, Brazil. Bot Mar 38:369-378

Shi J, Wei H (2009) Simulation of hydrodynamic structures in a semi-enclosed bay with dense raft-culture. Period Ocean Univ China 39:1181-1187 (in Chinese with English abstract)

* Sieburth JM (1969) Studies on algal substances in the sea. III. The production of extracellular organic matter by littoral marine algae. J Exp Mar Biol Ecol 3:290-309

Søndergaard M (1981) Kinetics of extracellular release of ${ }^{14} \mathrm{C}$-labelled organic carbon by submerged macrophytes. Oikos 36:331-347

* Tanaka Y, Ogawa H, Miyajima T (2011) Production and annual productionbacterial decomposition of dissolved organic matter in a fringing coral reef. J Oceanogr 67: 427-437

*Verity PG (1981) Effects of temperature, irradiance, and daylength on the marine diatom Leptocylindrus danicus 
cleve. I. Photosynthesis and cellular composition. J Exp Mar Biol Ecol 55:79-91

Wada S, Hama T (2013) The contribution of macroalgae to the coastal dissolved organic matter pool. Estuar Coast Shelf Sci 129:77-85

Wada S, Aoki MN, Tsuchiya Y, Sato T, Shinagawa H, Hama $\mathrm{T}$ (2007) Quantitative and qualitative analyses of dissolved organic matter released from Ecklonia cava Kjellman, in Oura Bay, Shimoda, Izu Peninsula, Japan. J Exp Mar Biol Ecol 349:344-358

Wada S, Aoki MN, Mikami A, Komatsu T and others (2008) Bioavailability of macroalgal dissolved organic matter in seawater. Mar Ecol Prog Ser 370:33-44

Wang X, Wu Y, Jiang Z, Ma Q, Zhang J, Liu S (2017) Quantifying aquacultur-derived dissolved organic matter in the mesocosms of sanggou bay using excitation-emission matrix spectra and parallel factor analysis. J World Aquacult Soc 48:909-926

Watanabe Y (1980) A study of the excretion and extracellular products of natural phytoplankton in Lake Nakanuma, Japan. Int Rev Gesamten Hydrobiol Hydrograph 65:809-834

Wood A, Van Valen L (1990) Paradox lost? On the release of

Editorial responsibility: Alejandro Buschmann,

Puerto Montt, Chile

Reviewed by: 5 anonymous referees energy rich compounds by phytoplankton. Mar Microb Food Webs 4:103-116

Wyatt KH, Rober AR, Schmidt N, Davison IR (2014) Effects of desiccation and rewetting on the release and decomposition of dissolved organic carbon from benthic macroalgae. Freshw Biol 59:407-416

Xiao XL, Xian SH, Zhang Y, Jiao NZ (2020) Quantification of biodegradable dissolved organic carbon in the ocean. Acta Microbiol Sinica 60:1090-1105 (in Chinese with English abstract)

Khang J, Fang J, Wang W, Du M, Gao Y, Zhang M (2012) Growth and loss of mariculture kelp Saccharina japonica in Sungo Bay, China. J Appl Phycol 24: 1209-1216

Zhang WX (1992) Aquaculture in Sangou Bay. China Ocean Press, Beijing (in Chinese)

* Zhu X, Zhang R, Liu S, Wu Y, Jiang Z, Zhang J (2017) Seasonal distribution of dissolved iron in the surface water of Sanggou Bay, a typical aquaculture area in China. Mar Chem 189:1-9

Zlotnik I, Dubinsky Z (1989) The effect of light and temperature on DOC excretion by phytoplankton. Limnol Oceanogr 34:831-839

Submitted: February 22, 2020

Accepted: December 29, 2020

Proofs received from author(s): April 23, 2021 